\title{
Mobility and Market Structure in the Dutch Daily Newspaper Segments
}

Citation for published version (APA):

van Kranenburg, H. L. (2002). Mobility and Market Structure in the Dutch Daily Newspaper Segments. Journal of Media Economics, 15(2), 107-123. https://doi.org/10.1207/S15327736ME1502_3

Document status and date:

Published: 01/01/2002

DOI:

10.1207/S15327736ME1502_3

Document Version:

Publisher's PDF, also known as Version of record

\section{Please check the document version of this publication:}

- A submitted manuscript is the version of the article upon submission and before peer-review. There can be important differences between the submitted version and the official published version of record.

People interested in the research are advised to contact the author for the final version of the publication, or visit the DOI to the publisher's website.

- The final author version and the galley proof are versions of the publication after peer review.

- The final published version features the final layout of the paper including the volume, issue and page numbers.

Link to publication

\footnotetext{
General rights rights.

- You may freely distribute the URL identifying the publication in the public portal. please follow below link for the End User Agreement:

www.umlib.nl/taverne-license

Take down policy

If you believe that this document breaches copyright please contact us at:

repository@maastrichtuniversity.nl

providing details and we will investigate your claim.
}

Copyright and moral rights for the publications made accessible in the public portal are retained by the authors and/or other copyright owners and it is a condition of accessing publications that users recognise and abide by the legal requirements associated with these

- Users may download and print one copy of any publication from the public portal for the purpose of private study or research.

- You may not further distribute the material or use it for any profit-making activity or commercial gain

If the publication is distributed under the terms of Article $25 \mathrm{fa}$ of the Dutch Copyright Act, indicated by the "Taverne" license above, 


\title{
Mobility and Market Structure in the Dutch Daily Newspaper Market Segments
}

\author{
Hans van Kranenburg \\ Department of Management Sciences/Strategy \\ Maastricht University
}

\begin{abstract}
This study analyzes how the market structure and intensity of competition in the Dutch daily newspaper industry have changed over the last decades. The industry comprises distinct market segments: national newspapers and regional ones. The dynamics in this industry are studied using a decomposed market share mobility statistic. Decomposing this statistic allows an analysis of the market share transfers of newspapers both between and within these market segments. It offers an appropriate analytical framework for the comparison of the intensity of competition in industries where geographical product differentiation is an important competitive strategic element as it is in the case of daily newspapers.
\end{abstract}

The evolution of the information and communications industries has been the subject of theoretical and empirical research in industrial economics. Studies such as Ferguson (1983), Kranenburg, Palm, and Pfann (1999), Norton and Norton (1986), Rosse (1967, 1970), Stigler (1964), and Thompson (1984, 1988, 1989) investigated the economic development and structure of the newspaper industry. These studies found evidence for the existence of product differentiation and economies of scale. They showed that over time, and particularly over the last decades, large-scale newspapers became more prominent and the newspapers' contents became more homogenous. Technological changes, such as the increase of transportation possibilities and the improvement of electronic communication, have transformed the industry structure from a geographically partitioned market to a more nationwide market.

Requests for reprints should be sent to Hans van Kranenburg, FDEWB, Department of Management Sciences/Strategy, Maastricht University, P.O. Box 616, 6200 MD Maastricht, The Netherlands. E-mail: h.vankranenburg@mw.unimaas.nl 
Key variables in explaining the dynamic market structure of this industry are the intensity of competition and the increase in production costs. The industry dynamics - such as changes in market share, concentration, and the strategic activities of newspapers-also depend on the heterogeneity among newspapers (e.g., Blankenburg, 1995; Bucklin, Caves, \& Lo, 1989; Hagner, 1983; Lacy \& Davenport, 1994; Lisby, 1991; Picard, Winter, McCombs, \& Lacy, 1988; Rosse, 1967; Thompson, 1989). Heterogeneity of newspapers arises from differences in capacity costs and first-copy costs. First-copy costs are ineluctable to produce even one copy and result from the collection and organization of editorial and advertising copy and preparation of the printing mechanism. Therefore, scale (the number of newspapers sold) is important to spread those costs over a larger circulation to reduce the average costs per newspaper and remain profitable. However, despite the importance of scale economies and the potential to achieve them by selling the newspaper in a larger area, many newspapers retain a distinctive local orientation. Geographic product differentiation is therefore an important characteristic of the market structure. It offers newspapers an important strategic tool in their competitive environment (e.g., Lacy \& Davenport, 1994; Thomson, 1984, 1989).

The daily newspaper industry in the Netherlands is characterized by geographic differentiation comprising distinct market segments: national newspapers and regional ones. The industry experienced a decline in the number of daily newspapers between 1950 and 1995, in particular in the regional markets. In 1950, 116 daily newspapers existed in the Netherlands of which 68 were editorially independent and only 11 were national in scope. In 1995, just 55 daily newspapers remained of which only 37 newspapers appeared editorially independent and 8 were national in scope. During this period, therefore, more than 60 newspapers exited the market. Their exit influenced the market structure considerably by repositioning the continuing newspapers and opening up possibilities for new entrants.

Market structure dynamics are usually studied using a range of concentration measures, such as Herfindahl and concentration ratios. Previous works (i.e., Alsem et al., 1982; Cuilenburg, Kleinnijenhuis, \& Ridder, 1988; Ridder, 1984) explored those measures for concentration in the Dutch newspaper industry. However, they did not show the relations between these measures and the changes in market shares of newspapers over time. This study fills this gap by extending Cable $(1993,1997)$ study, which decomposed the market share mobility statistic, an indicator of the changes in the market shares of firms over a period. This statistic takes into account that even when the traditional measures do not show any changes, considerable dynamics can still exist in the market. The decomposition as proposed in this study explicitly shows market entry and exit, market share transfers of newspapers between market segments, and market share transfers within market segments, and helps to identify the characteristics of entrants and exiting newspapers in the Dutch daily newspaper industry. 


\section{SOME MEASURES OF INDUSTRIAL CONCENTRATION}

In industrial organization literature, market structure is generally measured by concentration. Baldwin (1995), Davies (1979), and Caves (1998), for instance, provided an overview of concentration indexes. The most commonly used concentration measures are the concentration ratio (CR) - calculated as the percentage of output accounted for by a small number, generally four or five, of the largest firms in an industry $\left(\mathrm{CR}_{4}\right.$ or $\left.\mathrm{CR}_{5}\right)$ - and the Herfindahl index, or $\mathrm{H}$, which is a function of the number of firms and their market shares respectively. In general, the Herfindahl index emerged as a better tool to measure market concentration than the concentration ratios because it takes all the market players into consideration, and not just a few large ones.

Changes in the traditional concentration measures are generally small because the size distribution usually changes slowly over time (Baldwin, 1995). However, sometimes the concentration measures can indicate that the market structure changes very little, even though the market shares of individual firms may have changed significantly (a clear indication of industry dynamics). Some expressed concern is that some concentration measures may not adequately reveal the extent of the underlying change. Davies and Geroski (1997), for instance, found that the concentration is fairly stable in spite of considerable market share turbulence and changes among the surviving firms. Furthermore, Geroski, Machin, and Walters (1997) tried to explain the changes in market shares among firms. They showed that instantaneous individual shocks account for most of the variance in growth rates of market shares, whereas industry-level growth and innovations have less explanatory power. The process that takes place within an industry as firms enter and exit, grow and decline-whether via internal growth, mergers, or acquisitions-is not completely reflected in concentration statistics.

According to Baldwin and Gorecki (1994, p. 93), market share mobility statistics reflect these dynamic processes more accurately. Mobility and concentration indexes are complements because the two indexes reveal different aspects of the competitive process within industries (Baldwin \& Gorecki, 1994). The market share mobility statistics measure the intensity of competition, the market structure, and the evolution of an industry. The mobility in market shares depends strongly on basic features in an industry's technology and demand conditions, but seems largely independent of the direction and magnitude of the industrywide change (e.g., Caves, 1998; Dunne, Roberts, \& Samuelson, 1989). Hence, mobility statistics offer important additional insights on the intensity of competition.

\section{DECOMPOSITION OF MARKET SHARE MOBILITY}

An important property of market share mobility is that it embodies the level of concentration and its change, as well as the correlation of market shares over time (Ca- 
ble, 1993, 1997). Cable (1997) empirically illustrated the systematic relation between market share mobility and concentration for the national daily newspaper industry in the United Kingdom. The market share mobility $\left(\mathrm{M}_{\mathrm{t}}\right)$ between time 0 and $t$ is the sum of squared market share changes of all firms over the period. If all market shares are the same at time 0 and $t$, then $\mathrm{M}_{\mathrm{t}}=0$, and $\mathrm{M}_{\mathrm{t}}=2$ in an industry with complete market turnover, where one perfect monopolist replaces another. Formally, Cable decomposed the market share mobility measure $\mathrm{M}_{\mathrm{t}}$ over the time interval $[0, \mathrm{t}]$ as follows:

$$
M_{t}=\sum_{i=1}^{N}\left(m_{i, t}-m_{i, 0}\right)^{2}=\Delta H_{t}+2 H_{0}-2 \rho \sigma_{t} \sigma_{0}-2 / N
$$

where $\mathrm{m}_{\mathrm{i}, 0}$ and $\mathrm{m}_{\mathrm{i}, \mathrm{t}}$ are the market shares of firm i at time 0 and $\mathrm{t}$, respectively, $H_{0}=\sum_{i=1}^{N} m_{i, 0}^{2}$ is the Herfindahl index of the initial period concentration level, $\Delta \mathrm{H}_{\mathrm{t}}$ is the change in concentration measured by the Herfindahl indexes at time 0 and $t$. If a market consists of one firm, the Herfindahl index would be 1 , a perfect example of a monopoly. The value will decline to 0 when the number of firms in the market increases and their respective market shares become equal. The decomposition of the market share mobility as Cable specified also reveals the dispersion of market shares and the number of firms. The parameters $\sigma_{0}$ and $\sigma_{\mathrm{t}}$ denote the standard deviations of market shares at the beginning and the end of the period, respectively, and $\mathrm{N}$ includes all firms that have been in the market at some point between 0 and $\mathrm{t}$. The parameter $\rho$-the correlation between market shares at successive times 0 and $\mathrm{t}$ (clearly, $-1<\rho<1$ ) —is a measure of market share stability and shows the persistence of market shares through time (Gort, 1963). In other words, it indicates the ability of firms to maintain their relative position in the market over time. The closer the value of the parameter $\rho$ lies to 1 , the better firms could maintain their relative position in the market. (The formulas for measuring the decomposition of market share mobility are available from the author.)

Mobility statistics also reflect the process that takes place within an industry as firms enter and exit, grow and decline, via internal growth, mergers, or acquisitions. The indexes measure the outcome of the competitive process that results in the transfer of market shares from losers to winners in different market segments. Separating out the elements of mobility by firms with recognizable similar structural or strategic characteristics or due to entry, exit, or turnover of shares among continuing firms is possible. Therefore, the industrywide market share mobility is the sum of the market share mobilities between and within different subgroups in the industry. To analyze the subgroup structure of an industry, the market share mobility can also be disaggregated into K subgroups,

$$
M_{t}=\sum_{i=1}^{K} M_{t, i}
$$


where $\mathrm{M}_{\mathrm{t}, \mathrm{i}}$ represents the market share mobility of subgroup i. An interesting disaggregation is that between the subgroups: entering, exiting, and continuing firms. Caves and Porter (1977) emphasized that entrants and exiting firms are special cases of market share mobility. The initial market share of entrants starts at zero, the exiting firms' shares finish at zero, whereas continuing firms always have positive market shares. Identifying the characteristics of entering and exiting firms using a decomposition of their market share mobility, $\mathrm{M}_{\mathrm{t}}$ entry and $\mathrm{M}_{\mathrm{t}}$ exit, respectively, is possible. For all entrants observed in time interval $[0, \mathrm{t}]$,

$$
M_{t, \text { entry }}=\sum_{i=1}^{E N} m_{i, t}^{2}=\sigma_{\text {entry }}^{2}+\mu_{\text {entry }} \sum_{i=1}^{E N} m_{i, t}, m_{i, 0}=0 \text { and } m_{i, t}>0
$$

where EN includes all new entrants in the time period, $\sigma_{\text {entry }}^{2}$ denotes the variance in entrants' market shares $\left(\mathrm{m}_{\mathrm{i}, t}\right), \mu_{\text {entry }}$ is the mean of entrants' market shares, and $\sum_{i=1}^{E N} m_{i, t}$ is the joint market share of entrants in the industry. A similar decomposition can be done for exiting firms. For all exiting firms observed in time interval 0 and $\mathrm{t}$,

$$
M_{t, e x i t}=\sum_{i=1}^{E X} m_{i, 0}^{2}=\sigma_{\text {exit }}^{2}+\mu_{\text {exit }} \sum_{i=1}^{E X} m_{i, 0}, m_{i, 0}>0 \text { and } m_{i, t}=0
$$

where EX includes all exiting firms in the time period, $\sigma_{\text {exit }}^{2}$ denotes the variance in exiting firms' market shares $\left(\mathrm{m}_{\mathrm{i}, 0}\right), \mu_{\text {exit }}$ is the mean of exiting firms' market shares, and $\sum_{i=1}^{E X} m_{i, 0}$ is the joint market share of exiting firms at time 0 in the industry. Equations 3 and 4 confirm that the measured market share mobility over a given period embodies information on which firms enter or leave the industry. This subgroup decomposition provides a useful summary statistic of particular circumstances of the industry, capturing changes in the intensity of competition. For instance, the mean of the market share of entering and exiting firms and their variances and joint market shares show the impact of these firms on a industry, in particular on a concentrating industry. In such a case, which is common in the daily newspaper industry, knowing both what the average market share of entering firms must be and what the average market share of newspapers that did not or struggle to survive was is clearly important.

\section{THE DATA}

The longitudinal microeconomic database used to analyze the market structure and the intensity of competition in the daily newspaper industry is taken from the Dutch Central Bureau of Newspapers' Publicity (CEBUCO). The CEBUCO collects the annual circulation data of all editorially independent daily newspapers that existed 
in the Netherlands after 1950. CEBUCO's data collection makes tracing the volatility in market shares of entering, continuing, and exiting newspapers and in market segments over time possible. The data are thus well suited for a longitudinal study. In total 83 daily editorially independent newspapers in the Netherlands are identified after 1950. Editorial independence is typical phenomenon in the Netherlands. The editorial autonomy within the newspaper organization guarantees freedom of the press and freedom of opinion to protect publishers and editors from the influence and pressure of internal and external powers. The publishers are no longer the management directors. In Germany and England, for instance, the commercial and technical management and even the editor are unmistakably subordinated to the publisher (Hemels, 1997, p. 326). CEBUCO considers losing independency due to mergers, takeovers, or cessation of production as exit and considers becoming editorially independent as entry. Special-interest newspapers that appeared in the sample period are excluded from the data. Analyzing the volatility in market shares of the Dutch daily newspaper market is inspired by its nature, being linguistically demarcated and regionally segmented. In such a case, which is very uncommon in other industries, Dutch newspapers are only each other's competitors. They do not have to compete for their market share with foreign newspapers in the Netherlands. A shortcoming of this assumption is that we eliminate the competition among newspapers and media sources such as radio and television. Over the past decades newspapers had to compete with an increasing number of new media, particularly with regard to selling advertising space. Or as Ferguson (1983, p. 637) pointed out, "Advertisers seek to communicate with potential purchasers of their products or services. In a fundamental sense, what advertisers demand, and what the various advertising media outlets supply, are units of audience for advertising message." The newspaper industry in the Netherlands received financial compensation for advertising income losses caused by other media sources. Therefore, assuming that the competition in the daily newspaper market is mainly dominated by newspapers is plausible.

Kranenburg, Palm, and Pfann (1999) provided evidence on the political processes that have taken place in the Netherlands after World War II. Three phases are distinguished roughly. Phase 1 is characterized by a gradual decline of demand diversity that ended around 1970. It is followed by Phase 2, a strong period of polarization. Phase 3 starts at 1980 when the Dutch political parties were moving to the middle field of the political scene. With the loosening of traditionally political and religious ties many newspapers were forced to step away from their original background. The longitudinal data set is therefore split into three successive 15-year periods, 1950-1965, 1965-1980, and 1980-1995. Moreover, the three subperiods are long enough to remove most short-run or seasonal fluctuations so that the longer term and structural changes in the industry are captured in the statistics on mobility that are measured (Baldwin \& Gorecki, 1994). 


\section{THE DUTCH DAILY NEWSPAPER INDUSTRY}

The daily newspaper market is characterized by a high degree of product differentiation, which means that geographically partitioning is relevant in explaining the transfer of market shares from losers to winners. In an ongoing tendency of large-scale economies, newspaper's growth in size depends crucially on limited heterogenous resources, such as reading public, in the industry. The newspapers become larger and more general to specific, stimulating more competition in the market. The outcome of the competitive process in terms of transfer of market shares from losers to winners should be measured between and within the market segments. Three sets of disaggregation of market share mobility are used to characterize this process. The first set describes the intensity of competition, market structure, and the evolution in the national and regional market segments. The second set captures how overall market shares change due to entry by newspapers, exit by old ones, and turnover among continuing newspapers. The final set describes the relations between market share mobility, concentration, and its change in all market segments in the Dutch daily newspaper industry.

\section{National and Regional Newspapers}

Table 1 shows the decomposition of overall values of market share mobility over the three succeeding periods for the market as a whole and its national and regional market segments. Mobility in market shares is strongly related to the turnover that occurs within the national newspapers' market segment. Between 1950 and 1965 the market share mobility statistic for the whole market and the submarket for only national dailies is 0.01129 and 0.00899 , respectively. This implies that almost $80 \%$ of the volatility in the overall market share can be explained by the market share mobility of national newspapers. In the succeeding subperiods the volatility in regional market shares is becoming equally important in terms of volatility in market shares as that in the national newspapers. Although the relation between overall market share mobility and the mobility in national and regional market segments becomes relatively stable, the difference in concentration increases over time. The results show that an ongoing concentration tendency exists in the daily newspaper market, in particular in the national market segment. The Herfindahl index of the national newspaper submarket increased from 0.02327 in 1950 to 0.04470 in 1995. In 1995 the concentration in the national newspaper market contributes $74.8 \%$ to the overall Herfindahl index. Another interesting result is the pattern of the market share correlations $(\rho)$. It shows the extent to which shares at one point in time are dependent on those of 15 years later. Table 1 indicates without exception that the increase in concentration is associated with more stability according to the correlation coefficients. Over the whole period considered, the correlation between mar- 
TABLE 1

Decomposition of Market Share Mobility in National and Regional Newspapers Into Various Concentration Measures ${ }^{a}$

\begin{tabular}{|c|c|c|c|c|c|c|}
\hline Market & Period & $\begin{array}{c}\text { Market Share Mobility } \\
\text { Over the Period }\end{array}$ & $\begin{array}{c}\text { Initial } \\
\text { Herfindahl Index }\end{array}$ & $\begin{array}{l}\text { Herfindahl Index } \\
\text { at End of Period }\end{array}$ & $\begin{array}{c}\text { Change in } \\
\text { Concentration } \\
\text { Over the Period }\end{array}$ & $\begin{array}{c}\text { Correlation Between } \\
\text { Market Shares } \\
\text { Over the Period }\end{array}$ \\
\hline \multirow[t]{3}{*}{ Whole market } & 1950-1965 & 0.01129 & 0.03236 & 0.03669 & 0.00433 & 0.723 \\
\hline & 1965-1980 & 0.01117 & 0.03669 & 0.04526 & 0.00857 & 0.773 \\
\hline & 1980-1995 & 0.00579 & 0.04526 & 0.05978 & 0.01452 & 0.929 \\
\hline \multicolumn{7}{|l|}{ Submarket of only } \\
\hline & $1965-1980$ & 0.00537 & $0.01972^{\mathrm{b}}$ & 0.03033 & 0.01061 & 0.826 \\
\hline & 1980-1995 & 0.00337 & 0.03033 & 0.04470 & 0.01437 & 0.944 \\
\hline \multicolumn{7}{|l|}{ Submarket of only } \\
\hline regional dailies & 1950-1965 & 0.00230 & 0.00909 & $0.00919^{b}$ & 0.00010 & 0.698 \\
\hline & 1965-1980 & 0.00580 & $0.01696^{\mathrm{b}}$ & 0.01492 & -0.00204 & 0.633 \\
\hline & 1980-1995 & 0.00242 & 0.01492 & 0.01508 & 0.00016 & 0.803 \\
\hline
\end{tabular}

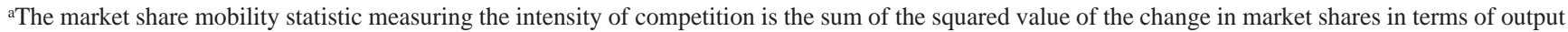
experienced by firms over the defined period. 'In 1965, the national newspaper, Het Vrije Volk, changed its circulation from nationwide to provincial. In the period 1950-1965, this newspaper has been considered as a national newspaper; and for the period 1965-1980, as a provincial newspaper. This explains the differences in the Herfindahl indexes. 
ket shares of national newspapers increased from 0.512 to 0.944 , whereas the regional newspapers showed a smaller increase. This implies that the market share of regional newspapers is still less stable. Moreover, the increase in the correlation values $(\rho)$ indicates a higher persistence of shares through time, in particular for national newspapers.

\section{Entering, Exiting, and Continuing Newspapers}

Very interesting is the subgroup decomposition of market share mobility in terms of entry, exit, and market share growth or decline for continuing newspapers in the concentrating newspaper industry in the Netherlands. Table 2 demonstrates the disaggregation of measured market share mobility of continuing newspapers. The number of continuing newspapers declined to 35 in 1995, and their market share became more stable. Between 1950 and 1995 the correlation between market shares increased from 0.777 to 0.927 .

This decomposition also allows the identification of the market share characteristics of entering and exiting newspapers in the industry. The importance of entry and exit can be measured either in terms of number of newspapers or their circulation. Table 3 presents the set of various concentration measures. Based on the number of entering and exiting newspapers, the industry has experienced an increase in competition after 1950. On the aggregate, more newspapers have exited the market. The intensity of competition is measured more accurately by the different aspects of the market share distribution. Table 3 presents the results of the magnitude of entry and exit through their market shares. The aggregate market share of exiting newspapers is significantly greater than the aggregate market share of entering newspapers in all three subperiods. Interestingly, the average market share of entering and exiting newspapers and their corresponding variations confirm the existence of large-scale economies. The average market share of entrants and the variation in market shares increased over time, whereas the average market share of exiting newspapers and variation decreased. This indicates that smaller editorially independent newspapers were forced to leave the market. Although the contribution of market share mobility of entering and exiting newspapers to the overall mobility is low, they still analyze the impact of entry and of intensified competition by incumbents. Exit accounts for a substantial 5.4\% to $15.2 \%$ of all mobility, and the continuing newspapers account for $83.0 \%$ to $91.9 \%$, which is confirmed by the joint market share variable. Because of fairly intense competition in the market place, exiting newspapers' market shares accounted for almost $15 \%$ in the first subperiod, which was mainly acquired by the continuing newspapers. In the periods following their contributions to the market share were $16.12 \%$ and $7.46 \%$, respectively. 
TABLE 2

Decomposition of Market Share Mobility of Continuing Dailies Into Various Concentration Measures Over the Defined Period

\begin{tabular}{lccccccc}
\hline Subgroup & Period & $\begin{array}{c}\text { Market Share Mobility } \\
\text { Over the Period }\end{array}$ & $\begin{array}{c}\text { Initial } \\
\text { Herfindahl Index }\end{array}$ & $\begin{array}{c}\text { Herfindahl Index } \\
\text { at End of Period }\end{array}$ & $\begin{array}{c}\text { Change in } \\
\text { Concentration } \\
\text { Over the Period }\end{array}$ & $\begin{array}{c}\text { Correlation Between } \\
\text { Market Shares } \\
\text { Over the Period }\end{array}$ & $\begin{array}{c}\text { Number of } \\
\text { Incumbents }\end{array}$ \\
\hline Continuing Dailies & $1950-1965$ & 0.00964 & 0.02899 & 0.03360 & 0.00461 & 0.777 & 53 \\
& $1965-1980$ & 0.00927 & 0.03360 & 0.04456 & 0.01096 & 0.809 & 41 \\
& $1980-1995$ & 0.00532 & 0.04456 & 0.05962 & 0.01506 & 0.927 & 35 \\
\hline
\end{tabular}


TABLE 3

Contribution of Entrants and Exiting Newspapers to Total Market Share Mobility Over the Defined Period and Their Characteristics

\begin{tabular}{|c|c|c|c|c|c|c|}
\hline Subgroup & Period & $\begin{array}{l}\text { Market Share Mobility } \\
\text { Over the Period }\end{array}$ & $\begin{array}{c}\text { Standard Deviation of } \\
\text { Newspapers' Market Share }\end{array}$ & $\begin{array}{c}\text { Average Market } \\
\text { Share of Newspapers }\end{array}$ & $\begin{array}{c}\text { Joint Market Share } \\
\text { of Newspapers }\end{array}$ & $\begin{array}{l}\text { Number of } \\
\text { Newspapers }\end{array}$ \\
\hline \multirow[t]{3}{*}{ Entering newspapers } & 1950-1965 & 0.00008 & 0.00238 & 0.00589 & 0.0118 & 2 \\
\hline & 1965-1980 & 0.00020 & 0.00443 & 0.00762 & 0.0229 & 3 \\
\hline & 1980-1995 & 0.00016 & 0.00700 & 0.00730 & 0.0146 & 2 \\
\hline \multirow[t]{3}{*}{ Exiting newspapers } & 1950-1965 & 0.00157 & 0.01172 & 0.00979 & 0.1469 & 15 \\
\hline & 1965-1980 & 0.00170 & 0.01152 & 0.00974 & 0.1612 & 14 \\
\hline & 1980-1995 & 0.00031 & 0.00829 & 0.00322 & 0.0746 & 9 \\
\hline
\end{tabular}




\section{Provincial Markets}

Despite the obvious importance of economies of scale for the newspaper industry, many daily newspapers retain a distinctive local orientation. Geographical product differentiation therefore is an important competitive strategic element in the daily newspaper industry in the Netherlands. Given the high degree of product differentiation, the industrywide market share mobility analysis must inevitably miss some of the subtleties of competition within market segments. Therefore, the market share mobility is also related to the structures of all market segments in the daily newspaper industry. The market segments are the industry as a whole and the 12 provinces in the Netherlands. One province, Flevoland, is excluded because no editorially independent daily newspaper appeared in the sample period. The province of origin of each regional daily newspaper is treated as its geographical market. The submarket divisions are widely accepted within and outside the industry. The criteria are socioeconomic profile of the readers, as well as formal and informal evaluation of content. The mobility statistics are based on the provincial (national) market shares of regional (national) newspapers in a particular market segment. Table 4 presents the market share mobility decomposition for the market segments.

The level of concentration, as measured by the Herfindahl indexes across the 12 market segments into which the daily newspaper industry is divided, increased (or stayed one in case only one newspaper appeared) in the sample period. An exception is the market Gelderland that experienced an increase in concentration level in the first subperiod and a declining level between 1965 and 1995. Although the concentration level increased in the sample period, the levels vary significantly between market segments. The values of the concentration statistics (Herfindahl indexes) vary between 0.12933 and 1 in 1950, and between 0.24955 and 1 in 1995 . Hence, the relative newspaper position may differ substantially in submarkets. In general, the correlation coefficients in Table 4 indicate that high concentration is associated with more stability. Interestingly, the relation between correlation coefficients and mobility is weak. Moreover, the difference in Herfindahl indexes is stronger related to market share mobility.

The market segment Drenthe experienced a complete market turnover where one perfect monopolist replaced another. This can be seen from the market share statistic $\left(\mathrm{M}_{\mathrm{t}}\right)$, which shows the extreme values 0 and 2 . The identity of newspapers changed in the first two subperiods, whereas the last monopolist determined the complete provincial circulation between 1980 and 1995. This example demonstrates clearly that the market share mobility statistic covers information that is not included in a concentration measure such as the Herfindahl index.

\section{CONCLUSION}

This study presented the relation between the market structure and intensity of competition in the Dutch market for daily newspapers by decomposing the market share mo- 
TABLE 4

Decomposition of Market Share Mobility Within Submarkets Into Various Concentration Measures

\begin{tabular}{|c|c|c|c|c|c|c|c|}
\hline Market Segment & Period & $\begin{array}{c}\text { Market } \\
\text { Share Mobility }\end{array}$ & $\begin{array}{c}\text { Initial } \\
\text { Herfindahl Index }\end{array}$ & $\begin{array}{l}\text { Herfindahl Index } \\
\text { at End of Period }\end{array}$ & $\begin{array}{c}\text { Change in } \\
\text { Concentration } \\
\text { Over the Period }\end{array}$ & $\begin{array}{c}\text { Correlation Between } \\
\text { Market Shares } \\
\text { Over the Period }\end{array}$ & $\begin{array}{l}\text { Number of } \\
\text { Newspapers }\end{array}$ \\
\hline \multirow[t]{3}{*}{ National } & 1950-1965 & 0.04521 & 0.13415 & $0.12464^{\mathrm{a}}$ & -0.00950 & 0.512 & 12 \\
\hline & 1965-1980 & 0.03085 & $0.13550^{\mathrm{a}}$ & 0.18318 & 0.04768 & 0.826 & 11 \\
\hline & 1980-1995 & 0.01799 & 0.18318 & 0.24955 & 0.06636 & 0.923 & 9 \\
\hline \multirow[t]{3}{*}{ Groningen } & 1950-1965 & 0.12902 & 0.36376 & 0.71004 & 0.34628 & 0.972 & 4 \\
\hline & 1965-1980 & 0.00012 & 0.71004 & 0.72027 & 0.01023 & 1.000 & 2 \\
\hline & 1980-1995 & 0.05654 & 0.72027 & 1.00000 & 0.27973 & 1.000 & 2 \\
\hline \multirow[t]{3}{*}{ Friesland } & 1950-1965 & 0.01053 & 0.37397 & 0.42585 & 0.05188 & 1.000 & 3 \\
\hline & 1965-1980 & 0.11276 & 0.42585 & 0.72400 & 0.29815 & 0.974 & 3 \\
\hline & 1980-1995 & 0.00005 & 0.72400 & 0.73059 & 0.00660 & 1.000 & 2 \\
\hline \multirow[t]{3}{*}{ Drenthe } & 1950-1965 & 2.00000 & 1.00000 & 1.00000 & 0.00000 & -1.000 & 2 \\
\hline & 1965-1980 & 2.00000 & 1.00000 & 1.00000 & 0.00000 & -1.000 & 2 \\
\hline & 1980-1995 & 0.00000 & 1.00000 & 1.00000 & 0.00000 & 1.000 & 1 \\
\hline \multirow[t]{3}{*}{ Overijssel } & $1950-1965$ & 0.00316 & 0.21001 & 0.21465 & 0.00464 & 0.888 & 5 \\
\hline & 1965-1980 & 0.03687 & 0.21465 & 0.27017 & 0.55519 & 0.748 & 5 \\
\hline & 1980-1995 & 0.92667 & 0.27017 & 0.44341 & 0.17324 & 0.968 & 4 \\
\hline \multirow[t]{3}{*}{ Gelderland } & 1950-1965 & 0.03164 & 0.39769 & 0.47642 & 0.07873 & 0.936 & 4 \\
\hline & 1965-1980 & 0.47642 & 0.47642 & 0.40452 & -0.07190 & 0.984 & 3 \\
\hline & 1980-1995 & 0.06302 & 0.40452 & 0.37316 & -0.03136 & 0.836 & 5 \\
\hline \multirow[t]{3}{*}{ Utrecht } & 1950-1965 & 0.02195 & 0.35671 & 0.41250 & 0.05579 & 0.939 & 4 \\
\hline & 1965-1980 & 0.07329 & 0.41250 & 0.61234 & 0.19984 & 0.958 & 3 \\
\hline & 1980-1995 & 0.13834 & 0.61234 & 1.00000 & 0.38766 & 1.000 & 2 \\
\hline \multirow[t]{3}{*}{ Noord-Holland } & 1950-1965 & 0.21328 & 0.20028 & 0.23604 & 0.03576 & 0.902 & 8 \\
\hline & 1965-1980 & 0.00349 & 0.23604 & 0.22037 & -0.01567 & 0.980 & 6 \\
\hline & 1980-1995 & 0.05568 & 0.22037 & 0.28935 & 0.06897 & 0.920 & 6 \\
\hline
\end{tabular}


TABLE 4 (Continued)

\begin{tabular}{|c|c|c|c|c|c|c|c|}
\hline Market Segment & Period & $\begin{array}{c}\text { Market } \\
\text { Share Mobility }\end{array}$ & $\begin{array}{c}\text { Initial } \\
\text { Herfindahl Index }\end{array}$ & $\begin{array}{l}\text { Herfindahl Index } \\
\text { at End of Period }\end{array}$ & $\begin{array}{c}\text { Change in } \\
\text { Concentration } \\
\text { Over the Period }\end{array}$ & $\begin{array}{c}\text { Correlation Between } \\
\text { Market Shares } \\
\text { Over the Period }\end{array}$ & $\begin{array}{l}\text { Number of } \\
\text { Newspapers }\end{array}$ \\
\hline \multirow[t]{3}{*}{ Zuid-Holland } & 1950-1965 & 0.06416 & 0.12933 & $0.16898^{\mathrm{a}}$ & 0.03965 & 0.538 & 12 \\
\hline & $1965-1980$ & 0.13352 & $0.22110^{\mathrm{a}}$ & 0.30681 & 0.08570 & 0.634 & 11 \\
\hline & 1980-1995 & 0.01186 & 0.30681 & 0.28269 & -0.24115 & 0.958 & 6 \\
\hline \multirow[t]{3}{*}{ Zeeland } & $1950-1965$ & 0.16492 & 0.42613 & 0.86862 & 0.44248 & 0.954 & 4 \\
\hline & $1965-1980$ & 0.00999 & 0.86862 & 1.00000 & 0.13138 & 1.000 & 2 \\
\hline & 1980-1995 & 0.00000 & 1.00000 & 1.00000 & 0.00000 & 1.000 & 1 \\
\hline \multirow[t]{3}{*}{ Noord-Brabant } & $1950-1965$ & 0.04254 & 0.15249 & 0.19335 & 0.04086 & 0.615 & 8 \\
\hline & 1965-1980 & 0.01004 & 0.19335 & 0.22672 & 0.03337 & 0.958 & 6 \\
\hline & 1980-1995 & 0.03011 & 0.22672 & 0.27980 & 0.05308 & 0.827 & 5 \\
\hline \multirow[t]{3}{*}{ Limburg } & 1950-1965 & 0.00117 & 0.28368 & 0.28832 & 0.00464 & 0.986 & 4 \\
\hline & 1965-1980 & 0.06291 & 0.28832 & 0.38587 & 0.09755 & 0.771 & 4 \\
\hline & 1980-1995 & 0.07822 & 0.38587 & 0.59132 & 0.20545 & 0.998 & 3 \\
\hline
\end{tabular}

aIn 1965, the national newspaper, Het Vrije Volk, changed its circulation from nationwide to provincial. In the period 1950-1965, this newspaper has been considered as a national newspaper; and for the period 1965-1980, as a provincial newspaper. This explains the differences in the Herfindahl indexes. 
bility statistic by market segments. Market share mobility reflects the turnover process that takes place within the industry as newspapers enter and exit, grow and decline. Decomposition of market share mobility shows explicitly the market share characteristics of newspapers entering, exiting, and continuing in the industry. Concentration depends strongly on cumulative effects of past market share mobility in a concentrated industry.

The results showed that the daily newspaper market is in an ongoing concentration process. However, the level of concentration varies significantly between market segments in the daily newspaper industry. Mobility in market shares is strongly related to the turnover that occurs within the national newspaper market. Although the contribution to market share mobility of entrants and exiting newspapers to the overall mobility is low, it still illustrates the impact of entry and of intensified competition by incumbents. The average size in market share and variation decreased for exiting newspapers and increased for entrants over time. In other words, newspapers, particularly those with a small market share, experience hard times in trying to survive in the concentrating newspaper industry, whereas entrants can only establish themselves in niche markets or need a larger scale to enter.

The difference among segments and strategic groups within the industry has illustrated that in a market characterized by high degree of product differentiation, the industrywide market share mobility does not completely capture the competition within market segments. The market share mobility statistic presented encompasses aspects of the competitive process in an industry such as the turnover of firms' market shares, concentration and its change, and the correlation of market shares over time. Understanding the relations between the intensity of competition, the market structure, and the evolution of the information and communications industries, separating out the elements of mobility due to entry, exit, and turnover of shares among continuing firms is advisable. The decompositions of market share mobility reveal the differences in impact of processes in information and communications industries. It shows the market share mobility statistic covers information that is not included in the traditional concentration measures.

\section{ACKNOWLEDGMENTS}

I thank Alan Albarran, Chris Allen, Joan Hemels, Annelies Hogenbirk, Franz Palm, Gerard Pfann, and three anonymous referees for their useful comments. I also thank Hetty van Sijl from the Dutch Central Bureau of Newspapers' Publicity for her assistance.

\section{REFERENCES}

Alsem, K. J., Boorsma, M. A., Helden, G. J. van, Hoekstra, J. C., Leeflang, P. S. H., \& Visser, H. H. M. (1982). De aanbodstructuur van de periodiek verschijnende pers in Nederland. 's-Gravenhage, The Netherlands: Staatsuitgeverij. 
Baldwin, J. R. (1995). The dynamics of industrial competition. Cambridge, England: Cambridge University Press.

Baldwin, J. R., \& Gorecki, P. K. (1994). Concentration and mobility statistics in Canada's manufacturing sector. Journal of Industrial Economics, 42, 93-103.

Blankenburg, W. B. (1995). Hard times and the news hole. Journalism \& Mass Communication Quarterly, 72, 634-641.

Bucklin, R. E., Caves, R. E., \& Lo, A. W. (1989). Games of survival in the U.S. newspaper industry. Applied Economics, 21, 631-649.

Cable, J. R. (1993). Market share mobility, entry and concentration change: A note. Aberystwyth Economic Research Papers, 93-09. University of Wales, Aberystwyth, England.

Cable, J. R. (1997). Market share behavior and mobility: An analysis and time-series application. Review of Economics and Statistics, 79, 136-141.

Caves, R. E. (1998). Industrial organization and new findings on the turnover and mobility of firms. Journal of Economic Literature, 36, 1947-1982.

Caves, R. E., \& Porter, M. E. (1977). From entry barriers to mobility barriers: Conjectural decisions and contrived deterrence to new competition. Quarterly Journal of Economics, 91, 241-261.

Cuilenburg, J. J. van, Kleinnijenhuis, J., \& Ridder, J. A. de (1988). Concentratie en persklimaat: Een empirisch onderzoek naar de mogelijkheid van een persbarometer [Politiologische studies]. Amsterdam: VU Uitgeverij.

Davies, S. (1979). Choosing between concentration indices: The iso-concentration curve. Economica, 46, 67-75.

Davies, S. W., \& Geroski. P. A. (1997). Changes in concentration, turbulence, and the dynamics of market shares. Review of Economics and Statistics, 79, 383-391.

Dunne, T., Roberts, M., \& Samuelson, L. (1989). Plant turnover and gross employment flows in the U.S. manufacturing sector. Journal of Labor Economics, 7, 48-71.

Ferguson, J. M. (1983). Daily newspaper advertising rates, local media cross-ownership, newspaper chains, and media competition. Journal of Law and Economics, 26, 635-654.

Geroski, P., Machin, S., \& Walters, C. (1997). Corporate growth and profitability. Journal of Industrial Economics, 45, 171-189.

Gort, M. (1963). Analysis of stability and change in market shares. Journal of Political Economy, 71, 51-63.

Hagner, P. R. (1983). Newspaper competition: Isolating related market characteristics. Journalism Quarterly, 60, 281-287.

Hemels, J. (1997). Social contextualization of the press: The Dutch case. Communications, 22, 317-341.

Kranenburg, H. L. van, Palm, F. C., \& Pfann, G. A. (1999). Concentration and shocks in the market for Dutch daily newspapers. Research Memorandum, RM/99/13. Maastricht, Netherlands: University of Maastricht.

Lacy, S., \& Davenport, L. (1994). Daily newspaper market structure, concentration, and competition. Journal of Media Economics, 7, 33-46.

Lisby, G. C. (1991). Predicting the failure of sister newspapers. Newspaper Research Journal, 12, $48-58$.

Norton, S. W., \& Norton, W. (1986). Economies of scale and the new technology of daily newspapers: A survivor analysis. Quarterly Journal of Economics and Business, 26, 66-83.

Picard, R. G., Winter, J. P., McCombs, M. E., \& Lacy, S. (Eds.) (1988). Press concentration and monopoly: New perspectives on newspaper ownership and operations. Norwood, NJ: Ablex.

Ridder, J. A. de (1984). Persconcentratie in Nederland, begripsvorming, bepaling en beschrijving. Amsterdam: VU Uitgeverij.

Rosse, J. N. (1967). Daily newspapers, monopolistic competition, and economies of scale. American Economic Review, 57, 522-533. 
Rosse, J. N. (1970). Estimating cost function parameters without using cost data: Illustrated methodology. Econometrica, 38, 256-275.

Stigler, G. J. (1964). A theory of oligopoly. Journal of Political Economy, 72, 44-61.

Thompson, R. S. (1984). Structure and conduct in local advertising markets: The case of Irish provincial newspapers. Journal of Industrial Economics, 33, 241-249.

Thompson, R. S. (1988). Product differentiation in the newspaper industry: An hedonic price approach. Applied Economics, 20, 367-376.

Thompson, R. S. (1989). Circulation versus advertiser appeal in the newspaper industry: An empirical investigation. Journal of Industrial Economics, 37, 261-271. 
Copyright of Journal of Media Economics is the property of Lawrence Erlbaum Associates and its content may not be copied or emailed to multiple sites or posted to a listserv without the copyright holder's express written permission. However, users may print, download, or email articles for individual use. 